\title{
Allyl functionalized phosphinite and phosphonite ligands: Synthesis, transition metal chemistry and orthopalladation reactions
}

\author{
SINGAPPAGUDEM GOVINDARAJU ${ }^{\mathrm{a}}$, GUDDEKOPPA S ANANTHNAG ${ }^{\mathrm{a}}$, SUSMITA NAIK ${ }^{\mathrm{a}}$, \\ SHAIKH M MOBIN $^{\mathrm{b}}$ and MARAVANJI S BALAKRISHNA ${ }^{\mathrm{a}, *}$

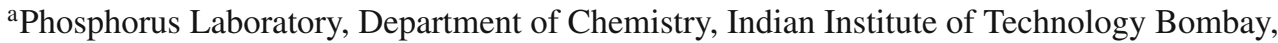 \\ Mumbai 400 076, India \\ b National Single Crystal X-ray Diffraction Facility, Indian Institute of Technology Bombay, \\ Mumbai 400 076, India \\ e-mail: krishna@chem.iitb.ac.in
}

MS received 28 December 2011; accepted 29 February 2012

\begin{abstract}
Allyl functionalized phosphinite $\mathrm{PPh}_{2}(\mathrm{OAr})\left[\mathrm{Ar}=\mathrm{C}_{6} \mathrm{H}_{4}\left(o-\mathrm{C}_{3} \mathrm{H}_{5}\right)\right](\mathbf{1})$ and phosphonite $\mathrm{PPh}(\mathrm{OAr})_{2}$ (2) ligands were prepared by the reactions of 2-allylphenol with $\mathrm{PPh}_{2} \mathrm{Cl}$ and $\mathrm{PPhCl}_{2}$, respectively. The ruthenium(II) complexes, $\left[\mathrm{Ru}\left(\eta^{6}-p\right.\right.$-cymene $\left.)\left(\mathrm{PPh}_{2}(\mathrm{OAr})\right) \mathrm{Cl}_{2}\right](3)$ and $\left[\mathrm{Ru}\left(\eta^{6}\right.\right.$ - $p$-cymene $\left.)\left(\mathrm{PPh}(\mathrm{OAr})_{2} \mathrm{Cl}_{2}\right)\right](\mathbf{4})$ were obtained by reacting 1 or 2 with $\left[\mathrm{Ru}\left(\eta^{6}-p \text {-cymene }\right) \mathrm{Cl}_{2}\right]_{2}$ in $2: 1$ molar ratios, respectively. Reactions of $\mathbf{1}$ or $\mathbf{2}$ with $\mathrm{AuCl}\left(\mathrm{SMe}_{2}\right)$ gave $\left[\mathrm{Au}\left\{\mathrm{PPh}_{2}(\mathrm{OAr})\right\} \mathrm{Cl}\right](\mathbf{5})$ or $\left[\mathrm{Au}\left\{\mathrm{PPh}(\mathrm{OAr})_{2}\right\} \mathrm{Cl}\right](\mathbf{6})$ in good yield. The palladium complex, $\left[\mathrm{Pd}\left\{\mathrm{PPh}(\mathrm{OAr})_{2}\right\}_{2} \mathrm{Cl}_{2}\right]$ (7) was prepared by reacting $\mathrm{Pd}(\mathrm{COD}) \mathrm{Cl}_{2}$ with 2 in 1:2 molar ratio. The reaction between $\mathrm{Pd}(\mathrm{COD}) \mathrm{Cl}_{2}$ and $\mathbf{1}$ yielded a mixture of orthopalladated cis- and trans $-\left[\mathrm{Pd}\left(\mathrm{Ph}_{2} \mathrm{P}(\mathrm{OAr})\right) \mathrm{Cl}\right]_{2}(\mathbf{8 a}$ and 8b). The treatment of $\mathbf{8}$ with $\mathrm{PPh}_{3}$ and $\mathrm{Ph}_{2} \mathrm{PCH}_{2} \mathrm{PPh}_{2}$ resulted in the cleavage of chloro bridge to give respectively, $\left[\mathrm{Ph}_{2}(\mathrm{OAr}) \mathrm{PPd}\left(\mathrm{PPh}_{3}\right) \mathrm{Cl}\right](\mathbf{9})$ and $\left[\mathrm{Ph}_{2}(\mathrm{ArO}) \mathrm{PPd}\left(\eta^{2}-\mathrm{dppm}\right)\right] \mathrm{OTf}(\mathbf{1 0})$. Single crystal X-ray structure of the ruthenium complex $\mathbf{3}$ is described.
\end{abstract}

Keywords. Phosphonites; palladium(II); orthopalladation; orthometallation; metal complexes; gold(I) and ruthenium(II) complexes.

\section{Introduction}

Phosphinite-metal complexes have become the most popular catalysts for several organic transformations because of their catalytic potential, easier synthetic methods and versatile coordination behaviour. ${ }^{1}$ Orthopalladated phosphinite complexes attracted much attention because of their excellent activity in $\mathrm{C}-\mathrm{C}$ and C-N couplings reactions. ${ }^{2,3}$ Several methods have been employed for the preparation of palladacycles, the preeminent ones being, the $\mathrm{C}-\mathrm{H}$ bond activation, oxidative addition of $\mathrm{C}-\mathrm{X}$ or $\mathrm{C}-\mathrm{C}$ bonds, transmetallation and addition of unsaturated bonds. The formation of palladacycles from phosphinite ligands is facile. The palladacycles contain carbon-palladium bond formed by an aromatic $\mathrm{C}-\mathrm{H}$ activation (ortho-activation). ${ }^{4}$ The majority of palladacycles contain one $\sigma\left(\mathrm{Pd}-\mathrm{C}_{\mathrm{sp} 2}\right)$ bond and a coordinate bond via donor atom to form fiveor six-membered metallacycles. Stable palladacycles usually contain five-membered rings. Larger rings are less stable as they often facilitate reductive elimination. ${ }^{5}$ In this paper, we describe the synthesis, transition

*For correspondence metal chemistry and orthopalladation reactions of olefin functionalized phosphinite and phosphonite ligands.

\section{Experimental}

All experimental manipulations were performed under an inert atmosphere of dry nitrogen or argon, using standard Schlenk techniques. All the solvents were purified by conventional procedures and distilled prior to use. ${ }^{6}\left[\mathrm{Pd}(\mathrm{COD}) \mathrm{Cl}_{2}\right],{ }^{7}\left[\mathrm{Ru}\left(\eta^{6} \text {-cymene }\right) \mathrm{Cl}_{2}\right]_{2},{ }^{8}$ and $\left[\mathrm{AuCl}\left(\mathrm{SMe}_{2}\right)\right]^{9}$ were prepared according to the published procedures. Other reagents were obtained from commercial sources and used after purification. The ${ }^{1} \mathrm{H}$ NMR and ${ }^{31} \mathrm{P}\left\{{ }^{1} \mathrm{H}\right\}$ NMR ( $\delta$ in ppm) spectra were recorded in Bruker $\mathrm{AV} 400$ spectrometer operating at 400 and $162 \mathrm{MHz}$, respectively. TMS and $85 \% \mathrm{H}_{3} \mathrm{PO}_{4}$ were used as internal and external standard for ${ }^{1} \mathrm{H}$ and ${ }^{31} \mathrm{P}\left\{{ }^{1} \mathrm{H}\right\} \mathrm{NMR}$, respectively. All the spectra were recorded in $\mathrm{CDCl}_{3}$ solutions with $\mathrm{CDCl}_{3}$ as internal lock; positive shifts lie downfield of the standard in all of the cases. The microanalyses were performed using a Carlo Erba Model 1112 elemental analyzer. Mass spectra were recorded using Waters Q-Tof micro (YA-105). 
The melting points were observed in capillary tubes and are uncorrected.

\subsection{Synthesis of $\mathrm{PPh}_{2}(\mathrm{OAr})\left[\mathrm{Ar}=\mathrm{C}_{6} \mathrm{H}_{4}\left(\mathrm{o}-\mathrm{C}_{3} \mathrm{H}_{5}\right)\right](\mathbf{1})$}

A solution of chlorodiphenylphosphine $(1.4 \mathrm{~mL} 1.72 \mathrm{~g}$, $7.68 \mathrm{mmol})$ in diethyl ether $(20 \mathrm{~mL})$ was added dropwise to a mixture of 2-allylphenol $(1 \mathrm{~mL}, 1.03 \mathrm{~g}$, $7.68 \mathrm{mmol})$ and triethylamine $(1.1 \mathrm{~mL}, 0.8 \mathrm{~g}, 7.8 \mathrm{mmol})$ also in diethyl ether $(20 \mathrm{~mL})$ under constant stirring at $0{ }^{\circ} \mathrm{C}$. The reaction mixture was allowed to warm to room temperature and stirred for $12 \mathrm{~h}$. The amine hydrochloride salt thus formed was filtered through a frit containing celite. All volatiles were removed under vacuum to give 1 as a colourless liquid. Yield: $90 \%(2.2 \mathrm{~g}) .{ }^{1} \mathrm{H}$ NMR $\left(400 \mathrm{MHz}, \mathrm{CDCl}_{3}\right)$ : 7.62-6.94 (m, $\left.\mathrm{ArH}, 14 \mathrm{H}\right)$, $5.96(\mathrm{~m}, \mathrm{CH}, 1 \mathrm{H}), 4.90\left(\mathrm{~m}, \mathrm{CH}_{2}, 2 \mathrm{H}\right), \delta 3.41\left(\mathrm{~d},{ }^{3} J_{\mathrm{HH}}=\right.$ $\left.6.1 \mathrm{~Hz}, \mathrm{CH}_{2}, 2 \mathrm{H}\right) .{ }^{31} \mathrm{P}\left\{{ }^{1} \mathrm{H}\right\} \mathrm{NMR}\left(162 \mathrm{MHz}, \mathrm{CDCl}_{3}\right): \delta$ 107.9 (s). MS (EI): $m / z=319.2(\mathrm{M}+1)$.

\subsection{Synthesis of $\mathrm{PPh}(\mathrm{OAr})_{2}(\mathbf{2})$}

To a stirred solution of dichlorophenylphosphine $(1.03 \mathrm{~mL}, 1.34 \mathrm{~g}, 7.6 \mathrm{mmol})$ in diethyl ether, $(20 \mathrm{~mL})$ was added drop-wise to a mixture of 2-allylphenol $(2 \mathrm{~mL}, 2.06 \mathrm{~g}, 15.3 \mathrm{mmol})$ and triethylamine $(2.2 \mathrm{~mL}$, $1.61 \mathrm{~g}, 16 \mathrm{mmol})$ in the same solvent $(20 \mathrm{~mL})$ at $0{ }^{\circ} \mathrm{C}$. The reaction mixture was allowed to warm to room temperature and stirring was continued for another $12 \mathrm{~h}$. The amine hydrochloride formed was filtered through a frit containing celite, all volatiles were removed under reduced pressure to give $\mathbf{2}$ as a colourless liquid. Yield: 95\% (5.4 g). ${ }^{1} \mathrm{H}$ NMR $\left(400 \mathrm{MHz}, \mathrm{CDCl}_{3}\right): \delta 7.86-6.99$ (m, ArH, 13H), $5.88(\mathrm{~m}, \mathrm{CH}, 2 \mathrm{H}), 4.96\left(\mathrm{~m}, \mathrm{CH}_{2}, 4 \mathrm{H}\right)$, $3.34\left(\mathrm{~m}, \mathrm{CH}_{2}, 4 \mathrm{H}\right) .{ }^{31} \mathrm{P}\left\{{ }^{1} \mathrm{H}\right\}$ NMR $\left(162 \mathrm{MHz}, \mathrm{CDCl}_{3}\right)$ : $\delta 158.4$ (s).

\subsection{Synthesis of $\mathrm{Ru}\left(\eta^{6}\right.$-p-cymene $)\left\{\mathrm{PPh}_{2}(\mathrm{OAr})\right\} \mathrm{Cl}_{2}(\mathbf{3})$}

A solution of $\left[\mathrm{Ru}\left(\eta^{6}-p \text {-cymene }\right) \mathrm{Cl}_{2}\right]_{2} \quad(0.036 \mathrm{~g}$, $0.058 \mathrm{mmol})$ in dichloromethane $(10 \mathrm{~mL})$ was added drop-wise to a solution of $\mathrm{PPh}_{2}(\mathrm{OAr})(0.037 \mathrm{~g}$, $0.116 \mathrm{mmol})$ in the same solvent $(5 \mathrm{~mL})$ at room temperature. The clear red coloured solution thus obtained was stirred for $4 \mathrm{~h}$. The solvent was removed under reduced pressure and the product was washed with pet ether to give $\mathbf{3}$ as a red crystalline solid. Yield: $87 \%$ (0.065 g). Mp: $145{ }^{\circ} \mathrm{C}$ (dec). Anal. Calcd for $\mathrm{C}_{31} \mathrm{H}_{33} \mathrm{Cl}_{2} \mathrm{OPRu}$ : C, 59.62; H, 5.33. Found: C, 59.64; $\mathrm{H}, 5.11 .{ }^{1} \mathrm{H}$ NMR $\left(400 \mathrm{MHz}, \mathrm{CDCl}_{3}\right): \delta 7.97-7.02(\mathrm{~m}$, $\mathrm{ArH}, 14 \mathrm{H}), 6.27(\mathrm{~m}, \mathrm{CH}, 1 \mathrm{H}), 5.22\left(\mathrm{~m}, \mathrm{CH}_{2}, 2 \mathrm{H}\right), 3.80$ $\left(\mathrm{d},{ }^{3} J_{\mathrm{HH}}=6.2 \mathrm{~Hz}, \mathrm{CH}_{2}, 2 \mathrm{H}\right), 2.51(\mathrm{~m}, \mathrm{CH}, 1 \mathrm{H}), 1.58$ (s, $\left.\mathrm{CH}_{3}, 3 \mathrm{H}\right), 0.70\left(\mathrm{~d},{ }^{3} \mathrm{~J}_{\mathrm{HH}}=7 \mathrm{~Hz}, \mathrm{CH}_{3}, 6 \mathrm{H}\right) .{ }^{31} \mathrm{P}\left\{{ }^{1} \mathrm{H}\right\}$ NMR (162 MHz, $\mathrm{CDCl}_{3}$ ): $\delta 113.6$ (s). MS (EI): $\mathrm{m} / z=$ $589.2(\mathrm{M}-\mathrm{Cl})$.

\subsection{Synthesis of $\left[R u\left(\eta^{6}-p \text {-cymene }\right) \mathrm{Cl}_{2}\left\{\mathrm{PPh}(\mathrm{OAr})_{2}\right\}\right]_{2}(\mathbf{4})$}

This was synthesized by a procedure similar to that of 3, using $2(0.04 \mathrm{~g}, 0.108 \mathrm{mmol})$ and $\left[\mathrm{Ru}\left(\eta^{6}-p\right.\right.$ cymene $\mathrm{Cl}_{2}$ ] (0.033 g, $\left.0.054 \mathrm{mmol}\right)$. Yield: $83 \%$ (0.064 g). Mp: $180-184{ }^{\circ} \mathrm{C}$. Anal. Calcd for $\mathrm{C}_{34} \mathrm{H}_{37} \mathrm{Cl}_{2} \mathrm{O}_{2} \mathrm{PRu}$ : C, 60.00; H, 5.48. Found: C, 59.20; H, 5.20. ${ }^{1} \mathrm{H}$ NMR $\left(400 \mathrm{MHz}, \mathrm{CDCl}_{3}\right): \delta 7.90-7.03(\mathrm{~m}, \mathrm{ArH}, 13 \mathrm{H}), 6.03$ $(\mathrm{m}, \mathrm{CH}, 2 \mathrm{H}), 5.41\left(\mathrm{~d},{ }^{3} J_{\mathrm{HH}}=6.4 \mathrm{~Hz}, \mathrm{CH}_{2}, 2 \mathrm{H}\right), 5.25$ $\left(\mathrm{d},{ }^{3} J_{\mathrm{HH}}=6.4 \mathrm{~Hz}, \mathrm{CH}_{2}, 2 \mathrm{H}\right), 5.16-5.10\left(\mathrm{~m}, \mathrm{CH}_{2}, 4 \mathrm{H}\right)$, $3.65\left(\mathrm{~m}, \mathrm{CH}_{2}, 4 \mathrm{H}\right), 2.73\left(\mathrm{~m},{ }^{3} J_{\mathrm{HH}}=7 \mathrm{~Hz}, \mathrm{CH}, 1 \mathrm{H}\right)$, $1.74\left(\mathrm{~s}, \mathrm{CH}_{3}, 3 \mathrm{H}\right), 1.02\left(\mathrm{~d},{ }^{3} J_{\mathrm{HH}}=7 \mathrm{~Hz}, \mathrm{CH}_{3}, 6 \mathrm{H}\right)$. ${ }^{31} \mathrm{P}\left\{{ }^{1} \mathrm{H}\right\}$ NMR $\left(162 \mathrm{MHz}, \mathrm{CDCl}_{3}\right): \delta 141.6$ (s). MS (EI): $m / z=644.8(\mathrm{M}-\mathrm{Cl})$.

\subsection{Synthesis of $\mathrm{Au}\left\{\mathrm{PPh}_{2}(\mathrm{OAr})\right\} \mathrm{Cl}(\mathbf{5})$}

A solution of $\mathrm{AuCl}\left(\mathrm{SMe}_{2}\right) \quad(0.028 \mathrm{~g}, 0.093 \mathrm{mmol})$ in dichloromethane $(10 \mathrm{~mL})$ was added drop-wise to a solution of $\mathbf{1}(0.03 \mathrm{~g}, 0.093 \mathrm{mmol})$ also in dichloromethane $(5 \mathrm{~mL})$ at room temperature. The reaction mixture was stirred for $4 \mathrm{~h}$, with minimum exposure to light. Then the solvent was removed under reduced pressure and product was isolated as a white solid. Yield: $85 \%$ (0.056 g). Mp: $172-174{ }^{\circ} \mathrm{C}$. Anal. Calcd for $\mathrm{C}_{21} \mathrm{H}_{19} \mathrm{AuClOP}: \mathrm{C}, 45.80 ; \mathrm{H}, 3.48$. Found: $\mathrm{C}$, 45.36; H, 3.54. ${ }^{1} \mathrm{H}$ NMR $\left(400 \mathrm{MHz}, \mathrm{CDCl}_{3}\right): \delta 7.02-$ $7.71(\mathrm{~m}, \mathrm{ArH}, 14 \mathrm{H}), 5.96(\mathrm{~m}, \mathrm{CH}, 1 \mathrm{H}), 4.97\left(\mathrm{~m}, \mathrm{CH}_{2}\right.$, $2 \mathrm{H}), 3.42\left(\mathrm{~d},{ }^{3} \mathrm{~J}_{\mathrm{HH}}=6.1 \mathrm{~Hz}, \mathrm{CH}_{2}, 2 \mathrm{H}\right) .{ }^{31} \mathrm{P}\left\{{ }^{1} \mathrm{H}\right\} \mathrm{NMR}$ $\left(162 \mathrm{MHz}, \mathrm{CDCl}_{3}\right): \delta 111.2$ (s).

\subsection{Synthesis of $\mathrm{Au}\left\{\mathrm{PPh}(\mathrm{OAr})_{2}\right\} \mathrm{Cl}(\mathbf{6})$}

This was synthesized by a procedure similar to that of 5, using $2(0.04 \mathrm{~g}, 0.1068 \mathrm{mmol})$ and $\mathrm{AuCl}\left(\mathrm{SMe}_{2}\right)$ $(0.0315 \mathrm{~g}, 0.1068 \mathrm{mmol})$. Yield: $79 \%(0.051 \mathrm{~g})$. Mp: $168{ }^{\circ} \mathrm{C}$ (dec). Anal. Calcd for $\mathrm{C}_{24} \mathrm{H}_{23} \mathrm{AuClO}_{2} \mathrm{P}: \mathrm{C}$, 47.50; H, 3.82. Found: C, 48.09; H, 2.79. ${ }^{1} \mathrm{H}$ NMR $\left(400 \mathrm{MHz}, \mathrm{CDCl}_{3}\right): \delta 8.07-7.18(\mathrm{~m}, \mathrm{ArH}, 13 \mathrm{H}), 5.79$ (m, $\mathrm{CH}, 2 \mathrm{H}), 4.96\left(\mathrm{~m}, \mathrm{CH}_{2}, 4 \mathrm{H}\right), 3.31\left(\mathrm{~m}, \mathrm{CH}_{2}, 4 \mathrm{H}\right)$. ${ }^{31} \mathrm{P}\left\{{ }^{1} \mathrm{H}\right\}$ NMR $\left(162 \mathrm{MHz}, \mathrm{CDCl}_{3}\right): \delta 135.1$ (s).

\subsection{Synthesis of $\left[\mathrm{Pd}\left\{\mathrm{PPh}(\mathrm{OAr})_{2}\right\}_{2} \mathrm{Cl}_{2}\right](7)$}

A solution of $\left[\mathrm{Pd}(\mathrm{COD}) \mathrm{Cl}_{2}\right](0.013 \mathrm{~g}, 0.046 \mathrm{mmol})$ in dichloromethane $(10 \mathrm{~mL})$ was added drop-wise to 
solution of $2(0.035 \mathrm{~g}, 0.92 \mathrm{mmol})$ in the same solvent $(5 \mathrm{~mL})$ at room temperature. The reaction mixture was stirred for $4 \mathrm{~h}$. The solvent was removed under vacuum, to get the product as a pale yellow solid. Yield: $91 \%$ (0.039 g). Mp: $156-160{ }^{\circ} \mathrm{C}$, Anal. Calcd for $\mathrm{C}_{48} \mathrm{H}_{46} \mathrm{Cl}_{2} \mathrm{O}_{4} \mathrm{P}_{2} \mathrm{Pd}: \mathrm{C}$, 62.25; H, 5.01. Found: $\mathrm{C}$, 61.21; $\mathrm{H}, 4.79 .{ }^{1} \mathrm{H}$ NMR $\left(400 \mathrm{MHz}, \mathrm{CDCl}_{3}\right): \delta 7.89-7.09(\mathrm{~m}$, ArH, 26H), 5.63 (m, CH, 2H), $4.86\left(\mathrm{~m}, \mathrm{CH}_{2}, 4 \mathrm{H}\right), 3.19$ $\left(\mathrm{d},{ }^{3} J_{\mathrm{HH}}=6.1 \mathrm{~Hz}, \mathrm{CH}_{2}, 4 \mathrm{H}\right) .{ }^{31} \mathrm{P}\left\{{ }^{1} \mathrm{H}\right\} \mathrm{NMR}(162 \mathrm{MHz}$, $\left.\mathrm{CDCl}_{3}\right): \delta 118.9(\mathrm{~s})$.

\subsection{Synthesis of $\left[\mathrm{Pd}\left\{\mathrm{PPh}_{2}(\mathrm{OAr})\right\} C l\right]_{2}(\mathbf{8 a}$ and $\mathbf{8 b})$}

A solution of $\left[\mathrm{Pd}(\mathrm{COD}) \mathrm{Cl}_{2}\right](0.152 \mathrm{~g}, 0.534 \mathrm{mmol})$ in toluene $(20 \mathrm{~mL})$ was added to solution of $\mathrm{PPh}_{2}(\mathrm{OAr})$ (1) $(0.17 \mathrm{~g}, 0.536 \mathrm{mmol})$ also in toluene $(20 \mathrm{~mL})$, and the solution was refluxed for $12 \mathrm{~h}$. The reaction mixture was allowed to cool to room temperature and filtered through celite. The solvent was removed under vacuo to give $\mathbf{8}$ as a yellow coloured solid. Yield: $80 \%(0.2 \mathrm{~g})$. Mp: $157-162{ }^{\circ} \mathrm{C}$. Anal. Calcd for $\mathrm{C}_{42} \mathrm{H}_{36} \mathrm{Cl}_{2} \mathrm{O}_{2} \mathrm{P}_{2} \mathrm{Pd}$ : C, 54.93; H, 3.95. Found: C, 55.77; H, 2.95. ${ }^{1} \mathrm{H}$ NMR $\left(400 \mathrm{MHz}, \mathrm{CDCl}_{3}\right): \delta 7.66-6.93(\mathrm{~m}, \mathrm{ArH}, 26 \mathrm{H}), 5.96$ (m, CH, 2H), $5.44\left(\mathrm{~m}, \mathrm{CH}_{2}, 4 \mathrm{H}\right), 3.30\left(\mathrm{~m}, \mathrm{CH}_{2}, 4 \mathrm{H}\right)$. ${ }^{31} \mathrm{P}\left\{{ }^{1} \mathrm{H}\right\} \mathrm{NMR}\left(162 \mathrm{MHz}, \mathrm{CDCl}_{3}\right): \delta 151.9$ (s) and 151.1 (s). MS (EI): $m / z=882.6(\mathrm{M}-\mathrm{Cl})$.

\subsection{Synthesis of $\left[\mathrm{Ph}_{2}(\mathrm{OAr}) \mathrm{PPd}\left(\mathrm{PPh}_{3}\right) \mathrm{Cl}\right](\mathbf{9 a}$ and $\mathbf{9 b})$}

A solution of $\mathrm{PPh}_{3}(0.025 \mathrm{~g}, 0.096 \mathrm{mmol})$ in toluene $(5 \mathrm{~mL})$ was added to a solution of $\mathbf{8 a}$ and $\mathbf{8 b}(0.041 \mathrm{~g}$, $0.048 \mathrm{mmol})$ in toluene $(10 \mathrm{~mL})$ at room temperature. The reaction mixture was stirred for $4 \mathrm{~h}$. The solvent was removed under reduced pressure to give $\mathbf{9}$ as a yellow solid. Yield: $82 \%$ (0.057 g). Mp: $159{ }^{\circ} \mathrm{C}$ (dec). Anal. Calcd for $\mathrm{C}_{39} \mathrm{H}_{33} \mathrm{ClOP}_{2} \mathrm{Pd}$ : C, 64.92; H, 4.61. Found: $\mathrm{C}, 65.59 ; \mathrm{H}, 5.18 .{ }^{1} \mathrm{H} \mathrm{NMR}\left(400 \mathrm{MHz}, \mathrm{CDCl}_{3}\right)$ :

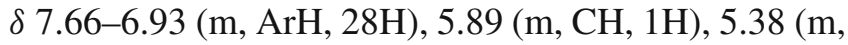
$\left.\mathrm{CH}_{2}, 2 \mathrm{H}\right), 3.37\left(\mathrm{~m}, \mathrm{CH}_{2}, 2 \mathrm{H}\right) .{ }^{31} \mathrm{P}\left\{{ }^{1} \mathrm{H}\right\} \mathrm{NMR}(162 \mathrm{MHz}$, $\left.\mathrm{CDCl}_{3}\right): \delta 156.2\left(\mathrm{~d},{ }^{2} J_{\mathrm{PP}}=29 \mathrm{~Hz}\right), 17.4\left(\mathrm{~d},{ }^{2} J_{\mathrm{PP}}=\right.$ $29 \mathrm{~Hz})$ and $146.6\left(\mathrm{~d},{ }^{2} J_{\mathrm{PP}}=439 \mathrm{~Hz}\right), 30.8\left(\mathrm{~d},{ }^{2} J_{\mathrm{PP}}=\right.$ $439 \mathrm{~Hz})$. MS (EI): $m / z=685.1(\mathrm{M}-\mathrm{Cl})$.

\subsection{Synthesis of $\left[\mathrm{Ph}_{2} P\left\{O \mathrm{C}_{6} \mathrm{H}_{3}\left(\mathrm{C}_{3} \mathrm{H}_{5}\right)-o\right\} P d\left(\eta^{2}-d p p m\right)\right]$ OTf (10)}

A solution of $\left[\left\{\mathrm{PPh}_{2}(\mathrm{OAr})\right\} \mathrm{PdCl}\right]_{2}(\mathbf{8})(0.042 \mathrm{~g}$, $0.045 \mathrm{mmol})$ in tetrahydrofuran $(10 \mathrm{~mL})$ was added drop-wise to a solution of bis(diphenylphosphino) methane (dppm) $(0.035 \mathrm{~g}, 0.091 \mathrm{mmol})$ and AgOTf
$(0.026 \mathrm{~g}, 0.1 \mathrm{mmol})$ in the same solvent $(5 \mathrm{~mL})$ at room temperature. The reaction mixture was stirred for $4 \mathrm{~h}$, then filtered through celite and the solvent was removed under reduced pressure to give $\mathbf{1 0}$ as yellow solid. Yield: $80 \%$ (0.074 g). Mp: $127-130{ }^{\circ} \mathrm{C}$. Anal. Calcd for $\mathrm{C}_{47} \mathrm{H}_{40} \mathrm{~F}_{3} \mathrm{O}_{4} \mathrm{P}_{3} \mathrm{PdS}$ : C, 58.97; $\mathrm{H}, 4.21$. Found: $\mathrm{C}$, 59.13; $\mathrm{H}$, 4.56. ${ }^{1} \mathrm{H}$ NMR $\left(400 \mathrm{MHz}, \mathrm{CDCl}_{3}\right): \delta 7.73-6.66$ (m, ArH, 33H), $5.98(\mathrm{~m}, \mathrm{CH}, 1 \mathrm{H}), 4.65\left(\mathrm{~m}, \mathrm{CH}_{2}, 2 \mathrm{H}\right)$, $3.19\left(\mathrm{~m}, \mathrm{CH}_{2}, 2 \mathrm{H}\right), 1.36\left(\mathrm{~d},{ }^{2} \mathrm{~J}_{\mathrm{PH}}=7 \mathrm{~Hz}, \mathrm{CH}_{2}, 2 \mathrm{H}\right)$. ${ }^{31} \mathrm{P}\left\{{ }^{1} \mathrm{H}\right\}$ NMR $\left(162 \mathrm{MHz}, \mathrm{CDCl}_{3}\right): \delta 149.7\left(\mathrm{dd},{ }^{2} J_{\mathrm{PP}}=\right.$ $385 \mathrm{~Hz}, 18 \mathrm{~Hz}),-20.8\left(\mathrm{dd},{ }^{2} J_{\mathrm{PP}}=385 \mathrm{~Hz}, 63 \mathrm{~Hz}\right)$ and $-25.7\left(\mathrm{dd},{ }^{2} J_{\mathrm{PP}}=63 \mathrm{~Hz}, 18 \mathrm{~Hz}\right)$. MS (EI): $\mathrm{m} / z=806.7$ (M-OTf).

\section{$2.11 X$-ray crystallography}

Single crystal X-ray structural study was performed on a CCD Oxford Diffraction XCALIBUR-S diffractometer equipped with an Oxford Instrument with lowtemperature attachment. Data were collected at 150(2) $\mathrm{K}$ using graphite-monochromated $\mathrm{Mo}-\mathrm{K}_{\alpha}$ radiation $\left(\gamma_{\alpha}=0.71073 \AA\right)$. The strategy for the data collection was evaluated by using the CRYSALISPRO CCD software. The data were collected by the standard 'phiomega scan' techniques and were scaled and reduced

Table 1. Crystallographic data for complex 3.

\begin{tabular}{lc}
\hline Empirical formula & $\mathrm{C}_{31} \mathrm{H}_{33} \mathrm{Cl}_{2} \mathrm{OPRu} . \mathrm{CHCl}_{3}$ \\
Fw & 743.88 \\
crystal system & Triclinic \\
space group & $\mathrm{P} 1$ \\
$a, \AA$ & $10.3415(3)$ \\
$b, \AA$ & $10.4132(4)$ \\
$c, \AA$ & $15.9431(5)$ \\
$\alpha$, deg & $87.380(3)$ \\
$\beta$, deg & $80.473(2)$ \\
$\gamma$, deg & $76.999(3)$ \\
$V, \AA^{3}$ & $1649.74(9)$ \\
$Z$ & 2 \\
$\rho_{\text {calc, gm }}{ }^{3}$ & 1.498 \\
$\mu(\mathrm{MoK} \alpha), \mathrm{mm}^{-1}$ & 0.953 \\
$F(000)$ & 756 \\
crystal size, mm & $0.230 .17 \times 0.14$ \\
$T(\mathrm{~K})$ & $150(2)$ \\
$2 \theta$ range, $\left(^{\circ}\right)$ & $3.30-25.00$ \\
total no. reflns & 12084 \\
no.of indep reflns & $5799\left[\mathrm{R}_{\text {int }} 0.0220\right]$ \\
GOF $\left(F^{2}\right)$ & 1.128 \\
$R_{1}^{\mathrm{a}}$ & 0.0367 \\
$w R_{2}^{\mathrm{b}}$ & 0.1091 \\
\hline &
\end{tabular}

${ }^{\mathrm{a}} \mathrm{R}=\Sigma\|\mathrm{Fo}|-| \mathrm{Fc}\| / \Sigma|\mathrm{Fo}|{ }^{\mathrm{b}} \mathrm{R}_{\mathrm{w}}=\left\{\left[\Sigma \mathrm{w}\left(\mathrm{F}_{\mathrm{o}}^{2}-\mathrm{F}_{\mathrm{c}}^{2}\right) / \Sigma \mathrm{w}\left(\mathrm{F}_{\mathrm{o}}^{2}\right)^{2}\right]\right\}^{1 / 2}$, $\mathrm{w}=1 /\left[\sigma^{2}\left(\mathrm{~F}_{\mathrm{o}}^{2}\right)+(\mathrm{xP})^{2}\right]$, where $\mathrm{P}=\left(\mathrm{F}_{\mathrm{o}}^{2}+2 \mathrm{~F}_{\mathrm{c}}^{2}\right) / 3$ 
using CRYSALISPRO RED software. The structure was solved by direct methods using SHELXS-97 and refined by full matrix least squares with SHELXL$97,{ }^{10}$ refining on $\mathrm{F}^{2}$. The positions of all the atoms were obtained by direct methods. All non-hydrogen atoms were refined anisotropically. The hydrogen atoms were placed in geometrically constrained positions and refined with isotropic temperature factors, generally $1.2 * \mathrm{U}$ eq of their parent atoms. Crystallographic data and other experimental details are summarized in table 1 and bond parameters are listed in table 2.

Table 2. Selected bond distances $(\AA)$ and bond angles $\left(^{\circ}\right)$ for $\mathbf{3}$.

\begin{tabular}{lllc}
\hline Bond distances $(\AA)$ & \multicolumn{3}{c}{ Bond angles $\left(^{\circ}\right)$} \\
\hline Ru1-Cl1 & $2.4126(8)$ & Cl1-Ru1-Cl2 & $87.58(3)$ \\
Ru1-Cl2 & $2.4112(8)$ & Cl1-Ru1-P1 & $88.16(3)$ \\
Ru1-P1 & $2.3120(8)$ & Cl2-Ru1-P1 & $91.14(3)$ \\
P1-C26 & $1.818(3)$ & O1-P1-C26 & $103.68(14)$ \\
P1-O1 & $1.627(2)$ & & \\
\hline
\end{tabular}

\section{Results and discussion}

The reaction of chlorodiphenylphosphine with 2allylphenol in $1: 1$ molar ratio at $0{ }^{\circ} \mathrm{C}$, in the presence of triethylamine leads to the formation of $\mathrm{Ph}_{2} \mathrm{P}(\mathrm{OAr})$ [Ar $\left.=\mathrm{C}_{6} \mathrm{H}_{4}\left(o-\mathrm{C}_{3} \mathrm{H}_{5}\right)\right]$ (1). A similar reaction of dichlorophenylphosphine with 2-allylphenol in 1:2 molar ratio gave $\mathrm{PhP}(\mathrm{OAr})_{2}$ (2), in good yield. The compounds $\mathbf{1}$ and $\mathbf{2}$ are air and moisture sensitive viscous liquids. The ${ }^{31} \mathrm{P}$ NMR spectra of $\mathbf{1}$ and $\mathbf{2}$ consist of single resonances at $107.8 \mathrm{ppm}$ and $158.4 \mathrm{ppm}$, respectively. ${ }^{1} \mathrm{H}$ NMR spectra of $\mathbf{1}$ and $\mathbf{2}$ show multiplets around 3.4 and $6.9 \mathrm{ppm}$ for allylic $\mathrm{CH}_{2}$ and $\mathrm{CH}$ protons, respectively. Mass spectrum of $\mathbf{1}$ shows a molecular ion peak at 319.2 corresponding to $\mathrm{M}+1$ ion.

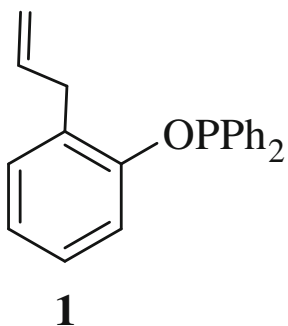<smiles>C=CCc1ccccc1OP(Oc1ccccc1)c1ccccc1</smiles>

The slow addition of dichloromethane solution of $\left[\mathrm{Ru}\left(\eta^{6}-p \text {-cymene }\right) \mathrm{Cl}_{2}\right]_{2}$ to $\mathbf{1}$ or $\mathbf{2}$ in $1: 2$ molar ratio at room temperature afforded $\left[\mathrm{Ru}\left\{\mathrm{PPh}_{2}(\mathrm{OAr})\right\}\left(\eta^{6}-p\right.\right.$ cymene $\left.) \mathrm{Cl}_{2}\right](3)$ and $\left[\mathrm{Ru}\left\{\mathrm{PPh}(\mathrm{OAr})_{2}\right\}\left(\eta^{6}-p\right.\right.$-cymene $\left.) \mathrm{Cl}_{2}\right]$ (4), respectively. The ${ }^{31} \mathrm{P}$ NMR spectrum of 3 shows a singlet at $113.6 \mathrm{ppm}$, whereas that of $\mathbf{4}$ appeared at $141.5 \mathrm{ppm}$. The ${ }^{1} \mathrm{H}$ NMR spectra of both the complexes are almost identical with the ligands, except peaks due to the $p$-cymene moiety. Mass spectra of $\mathbf{3}$ and $\mathbf{4}$ show peaks correspond to $\mathrm{M}-\mathrm{Cl}$ ions at $m / z 589.2$ and 644.8, respectively. The structure of $\mathbf{3}$ was confirmed by a single crystal X-ray diffraction study.

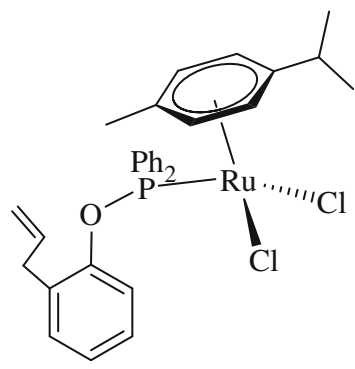

3

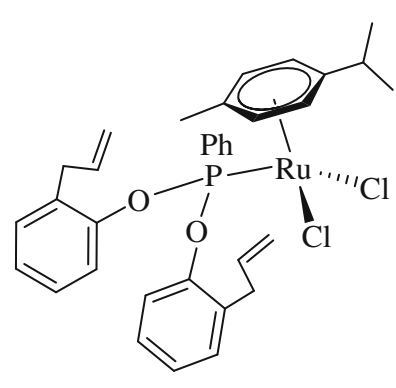

4
The treatment of $\mathrm{AuCl}\left(\mathrm{SMe}_{2}\right)$ with $\mathbf{1}$ or $\mathbf{2}$ in dichloromethane at room temperature resulted in the formation of $\left[\mathrm{Au}\left\{\mathrm{PPh}_{2}(\mathrm{OAr})\right\} \mathrm{Cl}\right]$ (5) and $\left[\mathrm{Au}\left\{\mathrm{PPh}(\mathrm{OAr})_{2}\right\} \mathrm{Cl}\right]$ (6). The ${ }^{31} \mathrm{P}$ NMR spectra of complexes 5 and $\mathbf{6}$ consist of single resonances, respectively, at $111.2 \mathrm{ppm}$ and $135.1 \mathrm{ppm}$. The reaction between $\mathrm{Pd}(\mathrm{COD}) \mathrm{Cl}_{2}$ and 2 affords $\mathrm{Pd}\left\{\mathrm{PPh}(\mathrm{OAr})_{2}\right\}_{2} \mathrm{Cl}_{2}$ (7). The ${ }^{31} \mathrm{P}$ NMR spectrum of compound 7 shows a sharp singlet at $118.8 \mathrm{ppm}$. The ${ }^{1} \mathrm{H}$ NMR and elemental analyses data are in accordance with the proposed structures.
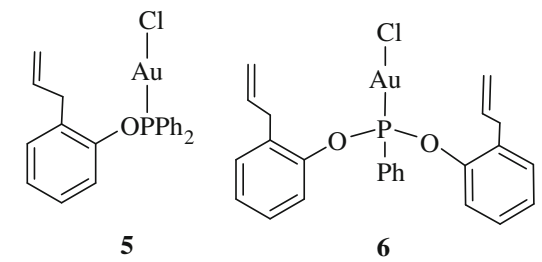

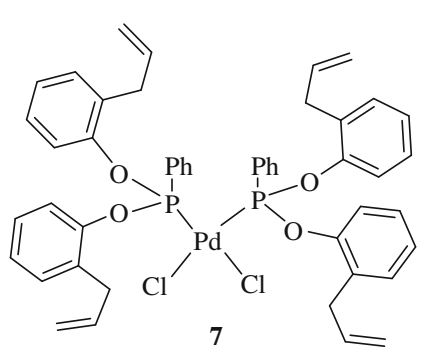




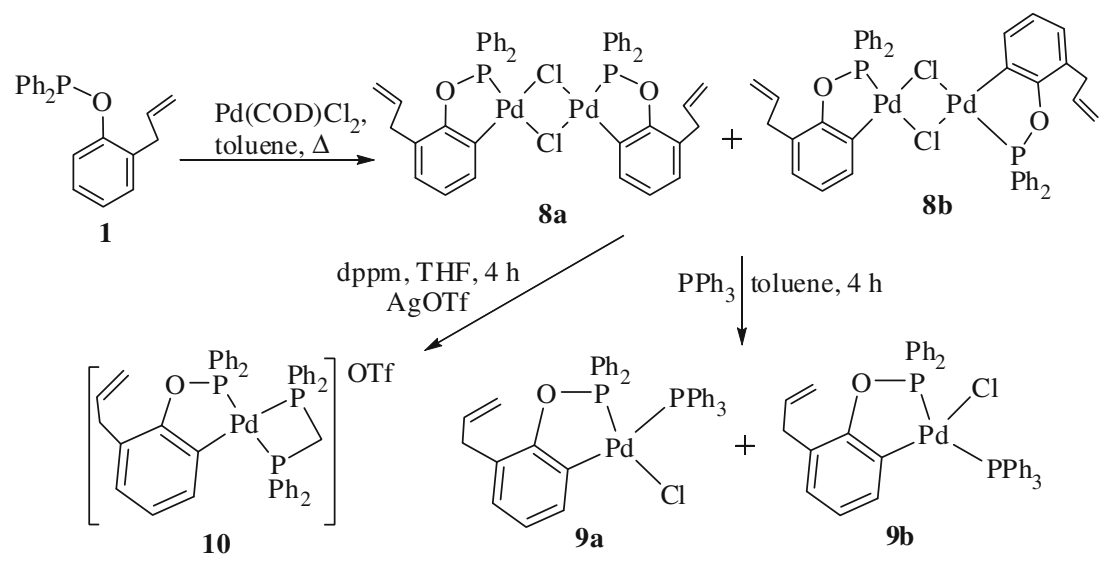

Scheme 1. Orthopalladation reaction of ligand 1.

The reaction of $\mathrm{Pd}(\mathrm{COD}) \mathrm{Cl}_{2}$ with $\mathrm{Ph}_{2} \mathrm{P}(\mathrm{OAr})$ (1) in toluene under reflux conditions yielded a mixture of $c$ is and trans isomers $\left[\mathrm{Pd}\left(\mathrm{PPh}_{2}(\mathrm{OAr})\right) \mathrm{Cl}\right]_{2}(\mathbf{8 a}$ and $\mathbf{8 b})$, in $1: 1$ ratio as confirmed by ${ }^{31} \mathrm{P}$ NMR spectrum, which show two singlets at 151.9 and $151.1 \mathrm{ppm}$, probably for cis and trans isomers, respectively (scheme 1). ${ }^{5}$ Evidence for orthometallation came from the elemental analysis, mass spectrometry and from further reactions. The cis and trans mixture (8a and $\mathbf{8 b}$ ) on treatment with one equivalent of triphenylphosphine in toluene at room temperature also afforded a mixture cis- and trans-[ $\left.\mathrm{Ph}_{2}(\mathrm{OAr}) \mathrm{PPd}\left(\mathrm{PPh}_{3}\right) \mathrm{Cl}\right](\mathbf{9 a}$ and $\mathbf{9 b})$, in 1:1 ratio, as indicated by its ${ }^{31} \mathrm{P}$ NMR spectrum. The presence of cis and trans isomers was unambiguously confirmed from its ${ }^{31} \mathrm{P}$ NMR spectrum due to the large difference in ${ }^{2} J_{\mathrm{PP}}$ values. The ${ }^{31} \mathrm{P}$ NMR spectrum of cis compound, 9a shows two doublets centered at 156.2 and $17.4 \mathrm{ppm}$ with a ${ }^{2} J_{\mathrm{PP}}$ of $29.2 \mathrm{~Hz}$, whereas trans complex, $9 \mathbf{b}$ consists of two doublets centered at 146.6 and $30.8 \mathrm{ppm}$ with a ${ }^{2} J_{\mathrm{PP}}$ of $438.9 \mathrm{~Hz}$. In mass spectrum, the mixture of $9 \mathbf{a}$ and $9 \mathbf{b}$ show a peak at $m / z 685.1$ for $\mathrm{M}-\mathrm{Cl}$ ion.

To further confirm the orthometallation reaction, the mixture of $\mathbf{8 a}$ and $\mathbf{8 b}$ was treated with bis(diphenylphosphino)methane (dppm) in the presence of silver triflate in tetrahydrofuran at room temperature to yield a cationic complex, $\left[\mathrm{Ph}_{2} \mathrm{P}\left\{\mathrm{OC}_{6} \mathrm{H}_{3}\left(\mathrm{C}_{3} \mathrm{H}_{5}\right)-o\right\}\right.$ $\mathrm{Pd}\left(\eta^{2}\right.$-dppm)]OTf (10). The ${ }^{31} \mathrm{P}$ NMR spectrum (see figure 1) of $\mathbf{1 0}$ consists of three doublet of doublets centered at $149.7 \mathrm{ppm},-20.8 \mathrm{ppm}$ and $-25.7 \mathrm{ppm}$, thus confirming the presence of three different phosphorus centers. A doublet of doublets at 149.7 with ${ }^{2} J_{\mathrm{PP}}$ of 385.3 and $17.8 \mathrm{~Hz}$ was assigned to coordinated phosphorus of phosphinite ligand. The upfield resonances at -25.7 and -20.8 were assigned to phosphorus centers

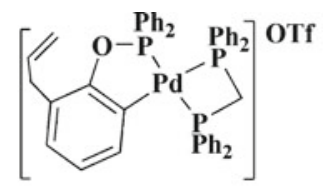

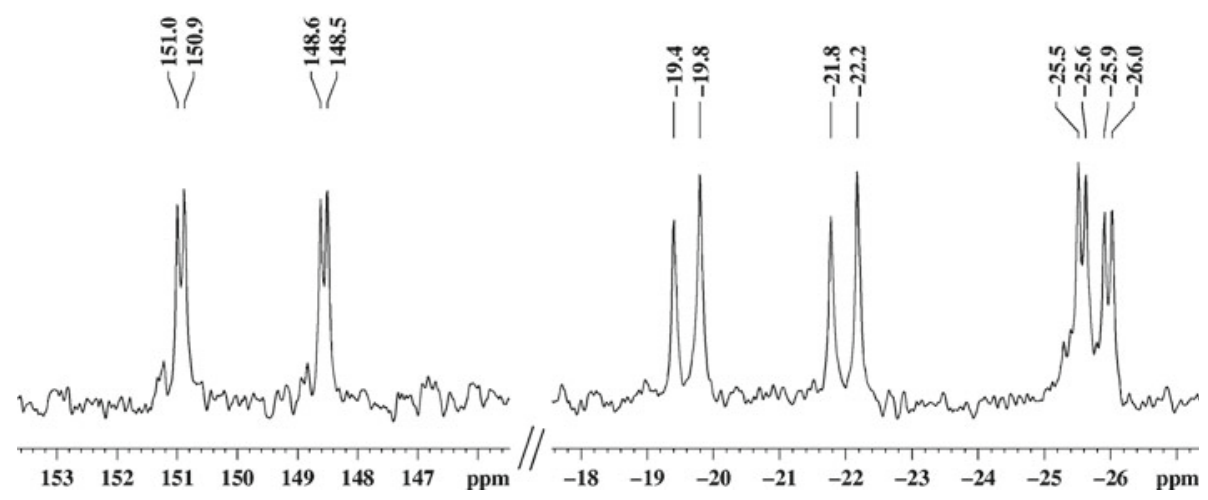

Figure 1. ${ }^{31} \mathrm{P}$ NMR spectrum of $\left[\mathrm{Ph}_{2} \mathrm{P}\left\{\mathrm{OC}_{6} \mathrm{H}_{3}\left(\mathrm{C}_{3} \mathrm{H}_{5}\right)-o\right\} \mathrm{Pd}\left(\eta^{2}-\mathrm{dppm}\right)\right] \mathrm{OTf}(\mathbf{1 0})$. 


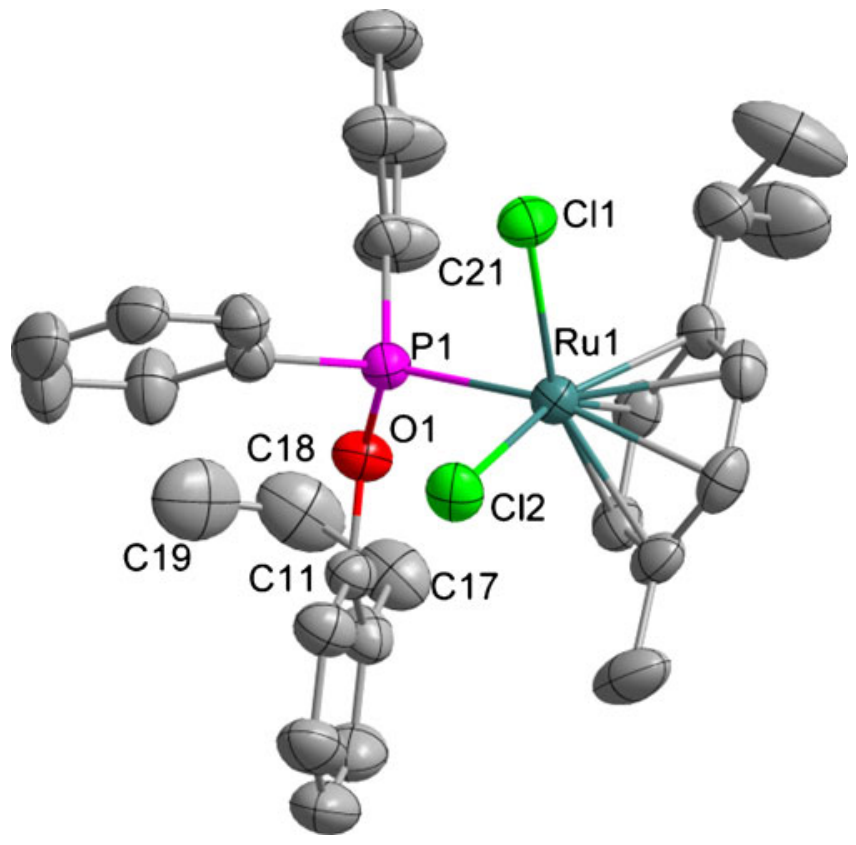

Figure 2. Crystal structure of complex 3 with atom numbering scheme. Thermal ellipsoids are drawn at the $50 \%$ probability level and all hydrogen atoms are omitted for clarity.

of dppm, cis and trans to phosphinite ligand, respectively. Mass spectrum of $\mathbf{1 0}$ shows a peak at $\mathrm{m} / z 806.7$ for M-OTf ion.

\section{1 $X$-ray structure analysis of $\left[R u\left\{P h_{2} P(O A r)\right\}\left(\eta^{6}-p-c y m\right) C l_{2}\right](3)$}

The crystals for single crystal X-ray diffraction study were obtained by the slow evaporation of chloroformpetroleum ether solution of $\mathbf{3}$ at room temperature. The crystallographic data are reported in table 1 , and the molecular structure of the complex $\mathbf{3}$ is shown in figure 2 while selected bond lengths and angles are listed in table 1 . The asymmetric unit contains one molecule of $\mathbf{3}$ and a $\mathrm{CHCl}_{3}$ molecule as solvent of crystallization. The ruthenium center consists of a $p$-cymene group, coordinated in $\eta^{6}$-fashion to form a three-legged 'piano-stool' structure, along with one phosphorus and two chloride ions. The Cl1-Ru-P1 and Cl2-Ru-P1 bond angles are $88.16^{\circ}$ and $91.14^{\circ}$, respectively. The $\mathrm{Cl} 1-\mathrm{Ru}-\mathrm{Cl} 2$ bond angle is $\left(87.58^{\circ}\right)$ comparable with the same observed in analogues ruthenium complexes containing tertiary phosphines. ${ }^{11}$

\section{Conclusion}

In summary, allyl functionalized phosphinite and phosphonite ligands and their palladium(II), gold(I) and
ruthenium(II) complexes were synthesized in good yield. The structure of ruthenium(II) complex (3) was determined by single crystal X-ray diffraction study which depicts ruthenium centre adopting typical pianostool geometry. Ligand 1 undergoes orthometallation on treatment with $\mathrm{Pd}(\mathrm{COD}) \mathrm{Cl}_{2}$ under reflux conditions.

\section{Supplementary information}

CCDC-870096 (3) contains the supplementary crystallographic data for this paper. This can be obtained free of charge from the Cambridge Crystallographic Data Centre via www.ccdc.cam.ac.uk/data_request/cif.

\section{Acknowledgements}

We thank the Department of Science and Technology (DST), New Delhi, for financial support for this work. GSA thanks the Council of Scientific and Industrial Research (CSIR), New Delhi, for research fellowships (JRF \& SRF). We also thank the Department of Chemistry and National Single Crystal X-ray Diffraction Facility, Indian Institute of Technology (IIT) Bombay, for spectral, analytical data and X-ray structure determination.

\section{References}

1. Agbossou F, Carpentier J F, Hapiot F, Suisse I and Mortreux A 1998 Coord. Chem. Rev. 178-180 1615

2. (a) Fairlamb I J S, Grant S, Tommasi S, Lynam J M, Bandini $\mathrm{M}$, Dong $\mathrm{H}$, Lin $\mathrm{Z}$ and Whitwooda A C 2006 Adv. Synth. Catal. 348 2515; (b) Bedford R B and Welch S L 2001 Chem. Comm. 129; (c) Punji B, Ganesamoorthy C and Balakrishna M S 2006 J. Mol. Catal. A: Chem. 25978

3. (a) Bedford R B, Hazelwood S L, Limmert M E, Brown J M, Ramdeehul S, Cowley A R, Coles S J and Hursthouse M B 2003 Organometallics 22 1364; (b) Bedford R B, Hazelwood S L, Horton P N and Hursthouse M B 2003 Dalton Trans. 4164; (c) Bedford R B, Blake M E, Coles S J, Hursthouse M B and Scully P N 2003 Dalton Trans. 2805; (d) Punji B, Mague J T and Balakrishna M S 2006 Dalton Trans. 1322; (e) Punji B, Mague J T and Balakrishna M S 2006 J. Organomet. Chem. 691 4265; (f) Punji B and Balakrishna M S 2006 Indian. J. Chem. 451390

4. Dupont J, Consorti C S and Spencer J 2005 Chem. Rev. 1052527

5. Beletskaya I P and Cheprakov A V 2004 J. Organomet. Chem. 6894055

6. Armarego W L F and Perrin D D 1996 Purification of laboratory chemicals 4th ed. Oxford UK: ButterworthHeinemann, Linacre House, Jordan Hill

7. Drew D and Doyle J R 1990 Inorg. Synth. 28346 
8. Jensen S B, Rodger S J and Spicer M D $1998 \mathrm{~J}$. Organomet. Chem. $\mathbf{5 5 6} 151$

9. Brandys M, Jennings M C and Puddephatt R J $2000 \mathrm{~J}$. Chem. Soc., Dalton Trans. 4601

10. Sheldrick G M SHELX-97 1997 A program for crystal structure solution and refinement
University of Gottingen, Germany (release 97-2)

11. (a) Balakrishna M S, Panda R and Mague J T 2002 J. Chem. Soc., Dalton Trans. 4617; (b) Albertin G, Antoniutti S, Castro J and Paganelli S $2010 \mathrm{~J}$. Organomet. Chem. 6952142 